Pesq. Vet. Bras. 36(5):417-422, maio 2016 DOI: $10.1590 / \mathrm{S} 0100-736 \mathrm{X} 2016000500011$

\title{
Patterns of arterial vascularization in swine hearts ${ }^{1}$
}

\author{
Maria G.F. Pinto ${ }^{2}$, Phelipe O. Favaron ${ }^{3 *}$, Dayane Alcântara ${ }^{3}$, Adriana R.A. Anunciação ${ }^{3}$, \\ Maria A. Miglino ${ }^{3}$, Vicenti Borelli ${ }^{3}$ and Antonio F. Filho ${ }^{3}$
}

\begin{abstract}
Pinto M.G.F., Favaron P.O., Alcântara D., Anunciação A.R.A., Miglino M.A., Borelli V. \& Filho A.F. 2016. Patterns of arterial vascularization in swine hearts. Pesquisa Veterinária Brasileira 36(5):417-422. Setor de Anatomia de Animais Domésticos e Selvagens, Departamento de Cirurgia, Faculdade de Medicina Veteronária e Zootecnia, Universidade de São Paulo, Av. Prof. Dr. Orlando Marques de Paiva 87, Cidade Universitária, Butantã, São Paulo, SP 05508-270, Brazil. E-mail: phelipe.favaron@yahoo.com.br

This study aimed to characterize the patterns of arterial vascularization in swine hearts. Ninety swine hearts were submitted to the Spalteholz diaphanization technique in order to dissect the coronary arteries. Three types of arterial vascularization patterns were characterized through the behaviorof the rami circumflexus and interventricularis, namely: balanced, right and left types. The balanced pattern was the most frequently (42.2\%); in this case, the rami circumflexus and interventricularis occupied their respective sulci. The right type (40\%) was further categorized into three vascularization subtypes. In the first, ramus circumflexus dexter branched from the ramus interventricularis subsinuosus. In the second, the arteria coronaria dextra branched from ramus interventricularis subsinuosus and ramus circumflexus. In the third model, arteria coronaria sinister branched from ramus interventricularis paraconalis. The left type (17.7\%) exhibited two subtypes. In the first, ramus interventricularis paraconalis ran through the entire corresponding sulcus and the ventral third of sulcus interventricularis subsinuosus, and ramus interventricularis subsinuosus occupied the dorsal and middle third of its respective sulcus. In the second, ramus interventricularis subsinuosus branched from arteria coronaria dextra and ran through the dorsal and medium thirds of its respective sulcus, and the ventral third was occupied by the collateral branch of ramus circumflexus sinister. Our results reinforce the thesis that the blood distribution system through the coronary artery in swine is similar to human, not only in qualitative but also by a quantitative comparison.
\end{abstract}

INDEX TERMS: Heart, cardiovascular system, coronary circulation, swine, animal models.

RESUMO.- [Padrões de vascularização arterial em corações de suínos.] Este estudo teve como objetivo caracterizar os padrões de vascularização arterial em corações de suínos. Para tanto, 90 corações de suínos foram submetidos à técnica de diafanização de Spalteholz com a finalidade de

\footnotetext{
${ }^{1}$ Received on April 25, 2015

Accepted for publication on January 17, 2016

${ }^{2}$ Setor de Anatomia de Animais Domésticos e Selvagens, Departamento de Anatomia dos Animais Domésticos, Escola de Medicina Veterinária, Universidade Federal da Bahia UFBA), Salvador, BA, Brasil. E-mail: pintogra@ufba.br

${ }^{3}$ Departamento de Cirurgia, Faculdade de Medicina Veterinária e Zootecnia (FMVZ), Universidade de São Paulo (USP), Av. Prof. Dr. Orlando Marques de Paiva 87, Cidade Universitária, São Paulo, SP 05508-270, Brasil. E-mails: dayanefisio@usp.br, anunciação@usp.br, miglino@usp.br, v.borelli@terra.com.br, pganatomiafmvz@usp.br; *Corresponding author: phelipe.favaron@yahoo.com.br
}

dissecar as artérias coronárias. Através do comportamento dos rami circumflexus e interventricularis caracterizou-se três modalidades de vascularização arterial do coração de suínos, sendo eles os tipos equilibrado, direito e esquerdo. 0 equilibrado foi observado com maior frequência (42,2\%), neste caso os rami circumflexus e interventricularis das artérias coronárias ocupavam seus respectivos sulcos. 0 tipo direito (40\%) apresentou três subtipos de vascularização. No primeiro o ramus circumflexus dexter ramificava-se formando o ramus interventricularis subsinuosus. No segundo, a arteria coronaria dextra emitia o ramus interventricularis subsinuosus e ramus circunflexus. E no terceiro modelo, da arteria coronaria sinistra emergia o ramus interventricularis paraconalis. 0 tipo esquerdo $(17,7 \%)$ apresentou dois subtipos. No primeiro, o ramus interventricularis paraconalis percorria todo o sulco correspondente e o terço ventral 
do sulcus interventricularis subsinuosus, o ramus interventricularis subsinuosus ocupava os terços dorsal e médio do seu respectivo sulco. No segundo, o ramus interventricularis subsinuosus oriundo da arteria coronaria dextra percorria apenas os terços dorsal e médio do seu respectivo sulco, ficando o terço ventral ocupado por colateral do ramus circumflexus sinister. Nossos resultados reforçam a tese de que a distribuição do suprimento sanguíneo pela artéria coronária em suínos é semelhante ao humano, não apenas de maneira qualitativa, mas também do ponto de vista quantitativo.

TERMOS DE INDEXAÇÃO: Coração, sistema cardiovascular, circulaçãoo coronária, suínos, modelos animais.

\section{INTRODUCTION}

The industrial sector of swine production has played a significant role in sustaining Brazil's economic development, with a great emphasis on export. Brazil is the third largest producer and fourth largest exporter of swine meat in the world, with a production of 3.49 million tons in 2012 (Abipecs 2012). The continuous production growth has been possible due to multidirectional efforts and investments ranging from knowledge related to health management, genetic improvement and advances in reproduction biotechnology techniques.

Additionally, due to morphological and physiological similarities with humans (Vidotti et al. 2008) the species has been used in medicine in comparative studies of various organs and systems. The species is also considered one of the main species used in translational research as an alternative to non-rodent species, such as dog and monkey (Swindle et al. 2012). With the creation of transgenic animals (Wolf et al. 2014)that exhibit a decreased expression of genes related to immune incompatibility (Satyananda et al. 2013), it may be possible to solve problems related to the low incidence of organ donors through xenotransplantation in the near future.

Swine have been widely used in studies involving the cardiovascular system, contributing significantly to the advancement of research (Guiney 1965, Hughes 1986), especially in studies of infarction extension and left ventricular remodeling after myocardial ischemia. Swine has also been used in the development of therapies for infarcted patients, such as pharmacological treatments, stem cell transplantation (Min et al. 2012, Li et al. 2013), and the use of angiogenic growth factors (Dixon \& Spinale 2009).

Banchi (1904) described the distribution of the coronary artery in humans and some animal species using the artery origin, which is largely responsible for the blood supply to the right posterior heart. Based on this criterion, cardiac irrigation can be divided into three patterns, right, left and balanced, which vary with respect to their participation in cardiac nutrition in different animal species.

According to Dixon \& Spinale (2009), although small animal models such as mice promote the understanding of the cellular and molecular basis of cardiovascular biology, to understand the mechanisms and biological bases of heart failure in humans, it is necessary to use large animals, which exhibit a similar clinical phenotype. Thus, swine have been widely used as a comparative model in recent years due to the anatomical and physiological similarities, both in normal and pathological conditions and in studies on acute heart failure (Santos et al. 2012), atherosclerosis (Artinger et al. 2009), valvular problems (Maluf et al. 1993, Grehan et al. 2000) and ventricular function (Hendry 1994).

Thus, a study that describes the different patterns of arterial vascularization of the swine heart, as well as the frequency of each type, will contribute significantly to the understanding of the arterial vascular relation ships in the heart, generating important data for the consolidation of the species as an experimental model for human medicine.

\section{MATERIALS AND METHODS}

Totally, 90 adult swine hearts from 3 different species were examined in this study: 30 Duroc (males), 30 Landrace (males) and 30 Mongrels (15 males and 15 females). The animals were from different swine farms in Sao Paulo and were slaughtered in the city of Sao Paulo. Immediately after euthanize the animals, the hearts were isolated and transported to the Laboratory of Anatomy, Department of Surgery, School of Veterinary Medicine and Animal Science of the University of Sao Paulo (Faculdade de Medicina e Veterinária da Universidade de São Paulo, FMVZ-USP), where they were submitted to analysis. The study was performed based on the principles advocated by the Ethics Committee on the use of animals of the same institution.

Initially, the origins of the coronary arteries were dissected and separately injected with gelatin aqueous solution $15 \% \mathrm{w} / \mathrm{v}$ stained by cinnabar (natural mercury sulfide CARLO ERBA S/A). Subsequently, the hearts were subjected to the Spalteholzdiaphanization process. The hearts were thus fixed in a $10 \%$ formalin aqueous solution for 72 hours, clarified in 20 volumes of hydrogen peroxide for 12 hours and dehydrated in a graded alcohol series l (70-95\%) and absolute alcohol for 72 hours. The samples were then cleared in benzene I and II for 72 hours each and a final solution of methyl salicylate ( 5 parts) and benzyl benzoate ( 3 parts).

This preparation of the hearts allowed for the behavioral analysis of the interventricular and circumflex branches of the right and left coronary arteries, which were photographed for description and interpretation. The data obtained were statistically analyzed with the aid of the two proportions test, with $\alpha=5 \%$ approach.

The nomenclature used was based on Veterinary Anatomical Nomenclature (1994) with additions previously proposed by Rickert (1955) and revisions of Habermehl (1959) regarding terminology for the right coronary artery branches.

\section{RESULTS}

This study identified three types of arterial vascularization of the heart in the swine model based on the behavior of rami circumflexus and interventricularis: a balanced model with the equal participation of both coronary arteries, a right-dominant model with three subtypes and a left-dominant model with two subtypes.

\section{Balanced-type arterial vascularization}

The balanced-type arterial vascularization was the most commonly observed pattern in swine hearts, i.e., in 38 cases $(42.2 \% \pm 5.2)$. More precisely, the pattern was obser- 
ved in 15 Duroc, 12 Landrace and 11 Mongrel animals. In these animals, the artéria coronária dextra branched into the ramus circumflexus dexter and ramus interventricularis subsinuosus, and the artéria coronaria sinister branched intothe ramus interventricularis paraconalis and ramus circumflexus sinister, branches which fully occupy their respective sulci, resulting in the balanced distribution of both coronary arteries in heart irrigation (Fig.1A,B).

\section{Right-type arterial vascularization}

The right-type arterial vascularization was observed at high frequency in swine hearts, i.e., in 36 cases $(40 \% \pm 5.1)$. More precisely, the pattern was observed in 14 Mongrel, 13 Duroc and 9 Landrace animals. In these cases, artéria coronária dextra was supplied by rami circumflexus dexter and interventricularis subsinuosus, which covered their respective coronarius and interventricularis sulci completely
A
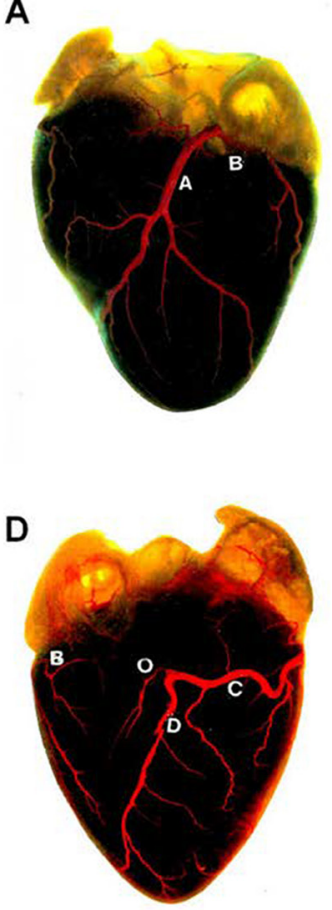

G

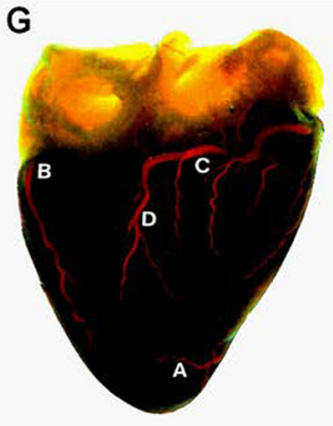

B

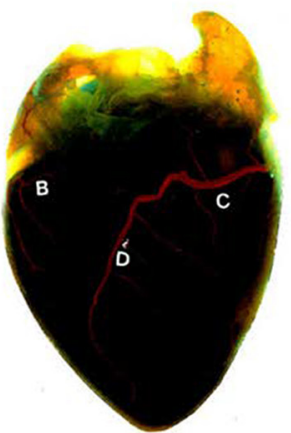

E

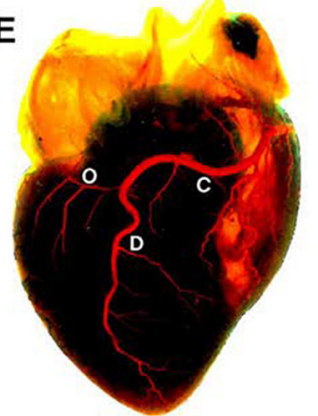

H

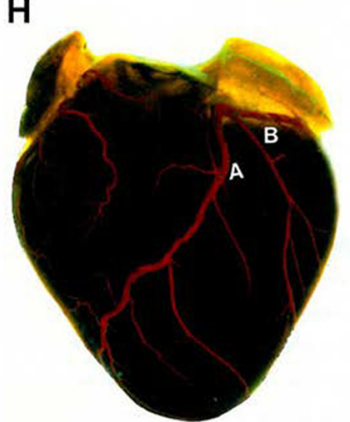

C

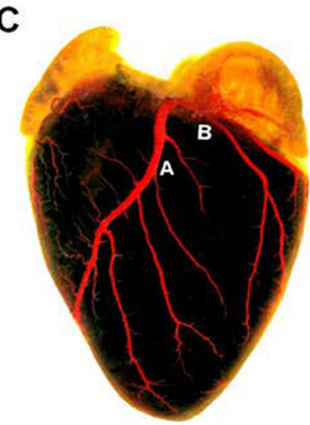

$\mathbf{F}$

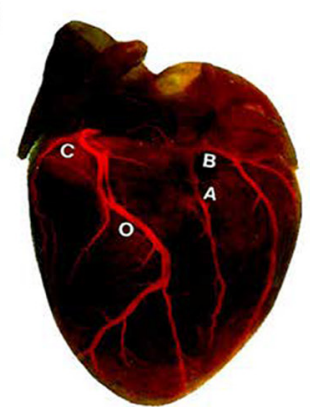

I

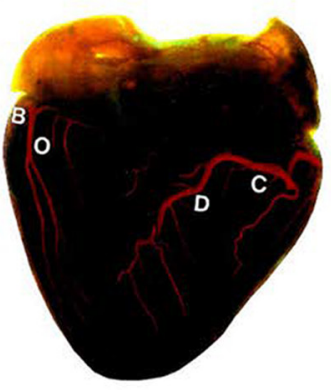

Fig.1. Patterns of swine heart vascularization after injection with gelatin and cinnabar solution and diaphanizationin xylene. (A,B) Balanced-type circulation in Mongrel breed swine. (A) Facies auriculari. (B) Facies atrialis. Note: ramus interventricularis paraconalis (A), ramus circumflexus sinister (B), ramus circumflexus dexter (C) and ramus interventricularis subsinuosus (D). (C,D,E) Right-type circulation in Mongrel breed swine. (C) Facies auricularis, in D and E: facies atrialis. Note in D: the ramus circumflexus dexter, and in C invading sulcus coronarius sinister through the collateral (0), ramus interventricularis subsinuosus (D) and ramus circumflexus sinister (D). Note in E: ramus circumflexus dexter (C) invading the sulcus coronarius sinister through the collateral (0) and ramus interventricularis subsinuosus (D). (F) Right-type circulation in Landrace breed swine. Note the ramus circumflexus sinister (B) and ramus interventricularis paraconalis (A) running through the dorsal half of sulcus interventricularis sinister, ramus circumflexus dexter (C), and the collateral of ramus circumflexus dexter (0), which circumvents the pulmonary cone to run through the ventral half of sulcus interventricularis sinister. (G,H,I) Left-type circulation in mongrel breed swine. In G and I: facies atrialisandin, in H: facies auricularis. Note in G: theramus circumflexus dexter (C) and the ramus interventricularis subsinuosus (D) running through the dorsal and medium thirds of the sulcus interventricularis dexter, and the ramus interventricularis paraconalis (A), reaching the ventral third of the sulcus interventricularis Dexter and the ramus circumflexus sinister (B). (I) Ramus interventricularis subsinuosus (D) running through the dorsal and medium thirds of sulcus interventricularis dexter and ramus circumflexus sinister (B) and the collateral of ramus circumflexus sinister (0) running towards the left ventricle wall and the ventral third of sulcus interventricularis dexter. 
and supplied a portion of the coronaries sulcus. The coronaries sulcus is commonly occupied by rami circumflexus and interventricularis paraconalis and branches from the right coronary artery with three subtypes of arterial vascularization:

In 33 hearts ( $36.6 \% \pm 5.0$ ), including 13 Duroc, 12 Mongrel and 8 Landrace animals, arteria coronaria sinister branched into ramus interventricularis paraconalis, which ran through the entire length of sulcus interventricularis sinister and ramus circumflexus sinister. The ramus circumflexus sinister partially occupied sulcus coronarius sinister after branching into amus interventricularis subsinuosus, which ran throughout the sulcus interventricularis dexter (Fig.1C,D).

In 2 hearts $(2.2 \pm 1.5 \%)$ belonging to Mongrels wine, both coronary arteries ceded their respective rami circumflexus and interventricularis. However, ramus circumflexus sinister occupied only half of the sulcus coronarius sinister. After the ramus circumflexus dexter branched vessels that ran through the other half of this sulcus, it branched into ramus interventricularis subsinuosus, which was identified throughout the length of sulcus interventricularis dexter (Fig.1E).

In only 1 heart $(1.1 \pm 1.0 \%)$ obtained from a Landrace swine, the arteria coronaria sinistra ceded the ramus circumflexus sinister, which occupies the entire length of sulcus coronarius sinister. The ramus interventricularis paraconalis ran only through the proximal half of sulcus interventricularis sinister and spread throughout the left ventricular wall, whereas ramus circumflexus of arteria coronaria dextra exhibited a ventricular branch immediately after its origin. After circumventing the conus arteriosus of truncus pulmonalis, the ventricular branch joined the sulcus interventricularis sinister, moving toward the cardiac apex. In this heart, the arteria coronaria dextra branched into the rami circumflexus dexter and interventricularis subsinuosus, which occupied the entire length of their respective sulci (Fig.1F).

\section{Left-type arterial vascularization}

The left-type arterial vascularization was observed with less frequency in swine hearts, i.e., in only 16 cases $(17.7 \%$ \pm 4.0 ). More precisely, the pattern was observed in 9 Landrace, 5 Mongrel, and 2 Duroc animals. In these cases, the artéria coronária dextra branched from ramus circumflexus dexter and ramus interventricularis subsinuosus. However, artéria coronária dextra did not totally occupy the sulcus interventricularis dexter, the ventral third of which was occupied either by the ramus interventricularis paraconalis of artéria coronaria sinister, after it circumvents the cardiac apex, or by the collateral of ramus circumflexus sinister, thus characterizing the predominance of artéria coronaria sinister in the heart's nutrition.

\section{Furthermore, in this group, the following subtypes were observed}

In 10 hearts $(11.1 \% \pm 3.3)$, including 7 Landrace, 2 Mongrel and 1 Duroc swine, the arteria coronaria dextra branched into ramus circumflexus dexter and ramus interventricularis subsinuosus, which ran through the dorsal and middle third of sulcus interventricularis dexter, whereas the arteria coronaria sinister branched into ramus interventricularis paraconalis and ramus circumflexus sinister. The ramus interventricularis paraconalis ran through sulcus interventricularis sinister to circumvent the cardiac apex and reach the ventral third of sulcus interventricularis dexter (Fig.1G).

In only 6 hearts $(6.6 \% \pm 2.6)$, from 3 Mongrel, 2 Landrace and 1 Duroc swine, the arteria coronaria dextra branched into ramus circumflexus dexter and ramus interventricularis subsinuosus. However, the arteria coronaria dextra only ran through the dorsal and middle thirds of the sulcus interventricularis dexter, whereas the arteria coronaria sinister branched into ramus interventricularis paraconalis and ramus circumflexus sinister, which occupy their respective sulci. Vessels branched from the ramus circumflexus sinister in the direction of the left ventricular wall to reach the ventral third of sulcus interventricularis dexter (Fig.1H,I).

The analysis of the results of the types of vascularization observed in the hearts of different breeds of swine revealed no statistically significant differences at $\alpha=5 \%$.

\section{DISCUSSION}

Animal models have contributed to the advancement of human medicine. In particular swine, which share many anatomical and physiological characteristics with humans, are potentially the best model for some procedures and studies when compared with other species (Swindle et al. 2012). The systems most commonly cited in the literature are the cardiovascular, urinary, cutaneous and digestive systems, what has led to an increase in the use of swinein toxicology and preclinical studies (Tumbleson \& Schook 1996, Swindle 2007, Swindle et al. 2012).

Several studies on the blood supply of the swine heart, which exhibits similarities with the human model, have been conducted previously (Swindle \& Adams 1988, Kassab 1994, Swindle \& Smith 1998, Swindle 2007). In addition, the sizes of the heart and blood vessels in sexually mature individuals more closely resemble those of the human heart than do other animal species such as dogs and primates (Swindle et al. 2012).

Differences have been observed in mammalian coronary arteries during myocardial nutrition analysis. These differences result from the various modalities of vascularization that has promoted the analysis and classification by numerous authors. The classic work of Banchi (1904) used the origin of the artery that nourishes the posterior face of the right heart as classification criteria and described three types of blood supply: balanced, right and left.

In the participation equilibrium of both coronary arteries in the myocardial nutrition, each coronary artery was observed to occupy its respective coronary and interventricular sulcus; the behavior of the rami circumflexus sinister and interventricularis paraconalis, branching from artéria coronária sinistra, and the rami circumflexus dexter and interventricularis subsinuosus, branching from artéria coronária dextra, supplied equivalent nutrition. In swine, this type of balanced vascular arrangement occurred most 
frequently, i.e., in 38 cases $(42.0 \% \pm 5.2)$. In this type of vascularization, the collaterals branched from rami interventricularis paraconalis and subsinuosus; whether these collaterals reached the corresponding ventricles was not taken into account. With respect to the prevalence of the artéria coronária dextra in pigs, such dominance occurs very frequently, in 36 cases in this study $(40.0 \% \pm 5.1)$.

It was possible to identify three types of vascularization in these hearts. In the most frequent case, i.e., in 33 cases $(36.6 \% \pm 5.0)$, the medial collateral of ramus circumflexus dexter occupied a third of the sulcus coronarius sinister after branching into the ramus interventricularis subsinuosus. In the second, less frequent case, i.e., in 2 cases $(2.2 \%$ \pm 1.54 ), ramus circumflexus sinister supplied the majority of the sulcus, whereas the other half of the sulcus was occupied by the ramus circumflexus dexter collateral. In the third case, which occurred only once $(1.1 \% \pm 1.0)$, ramus interventricularis paraconalis ran only through the superior half of the corresponding sulcus interventricularis, the inferior half of which was reached by ramus interventricularis collateral and ramus circumflexus dexter collateral. It is worthy to note that in swine, the ramus interventricularis subsinuosus never exceeded the cardiac apex to reach the sulcus interventricularis paraconalis. In swine, the artéria coronária sinistra is observed less frequently, in 16 cases in this study $(17.7 \% \pm 4.0)$. In these cases, two types of vascularization were observed: in 10 cases $(11.1 \% \pm 3.3)$, ramus interventricularis subsinuosus, branching from arteria coronaria dextra, covered only the dorsal and middle thirds of sulcus interventricularis subsinuosus, and the ventral third depends on ramus interventricularis paraconalis, which circumvents the cardiac apex. In 6 cases $(6.6 \% \pm 2.6)$, the ventral third of sulcus interventricularis subsinuosusis supplied by ramus circumflexus sinister collateral, previously ramus interventricularis subsinuosus, branching from artéria coronária dextra, which runs only the dorsal and middle thirds of the sulcus.

In swine, ramus interventricularis subsinuosus was never observed to branch from ramus circumflexus sinister nor the ramus interventricularis paraconalis, but was observed as a direct continuation of ramus circumflexus dexter, what allows us to conclude that in these animals, despite the different vascularization modalities identified, there is a significant trend of balance in the distribution of the main branches of the coronary arteries, what is beneficial if these results occur regardless of the genetic background.

Considering the information obtained in the treaties dedicated to Veterinary Anatomy, Bossi (1909), Lesbre (1923), Mannu (1930), Garcia \& Alvarez (1961), Bruni \& Zimmerl (1977), Ellenberger \& Baum (1977) and Dyce et al. (1990) do not make specific reference to swine. Only generic descriptions relevant to the behavior of the coronary arteries were found, what generally coincided with that observed in swine. The afore mentioned authors concluded that both coronary arteries provide circumflex and intraventricular branches that occupy their respective sulci.

Furthermore, the compendiums that focus on some aspects of the anatomy of swine, including the behavior of the coronary arteries, were analyzed. Montané \& Bourdelle
(1920), Koch (1965), Schwarze \& Schroder (1972), Sisson \& Grossman (1975) and Schummer et al. (1981) provided similar general descriptions that had been reported previously by other studies but contained no novel information, like the results observed in the present study, as they simply affirmed that the coronary arteries branch into the corresponding ramus circumflexus and interventricularis without registering any variation pertaining to these vessels.

Past studies that used swine (Rickert 1955, Martini 1965, Hoffmann 1975) or reviews that include this species (Marques 1962), although rich in information concerning the origin and distribution of all collateral coronary arteries, are not concerned with identifying a possible predominance of these arteries with respect to myocardial nutrition and do not describe changes that could be compared with the results found in the present study. However, in general, the behavior described by these authors with respect to the main branches from the coronary arteries does not differ, in theory, from the results found in the present study.

Regarding comparisons to the human model, recent studies (Swindle et al. 2012) have reported that the distribution system of the blood supply through the coronary arteries in swineis similar to the humans. The results of this study showed a predominance of a dominant conduction system of the balanced type (42.2\%) followed by the right (40.0\%).

Finally, the results obtained and presented herein are of great value because experimental studies now in development will grant swine an important role in the evolution of cardiac transplants.

Thus, further studies on this species are needed to elucidate important aspects in the vascularization of the myocardium of these animals, such as a detailed analysis of the contributions from ramus interventricularis paraconalis and subsinuosus, with respect to the nutrition of the ventricular walls to offer the indispensable informationto aid the progress of cardiovascular surgery.

With respect to the behavior of ramus circumflexus and interventricularis of the swine heart, three types of vascularity were identified: the balanced type (42.2\%), the right type $(40.0 \%)$ and the left type $(17.7 \%)$, with no statistically significant differences with respect to the type of vascularization in the different breeds studied $(\alpha=5 \%)$. This result qualitatively reinforces the hypothesis that the distribution system of the blood supply through the coronary arteries in swineis similar to that in humans.

\section{REFERENCES}

Abipecs 2012. Associação brasileira da indústria produtora e exportadora da carne suína. Embrapa. <http://www.abipecs.org.br/uploads/relatorios/relatoriosassociados/ABIPECS_relatorio_2012_pt.pdf>

Artinger S., Deiner C., Loddenkemper C., Schwimmbeck PL., Schultheiss H.P. \& Pels K. 2009. Complex porcine model of atherosclerosis: induction of early coronary lesions after long-term hyperlipidemia without sustained hyperglycemia. Can. J. Cardiol. 25(4):109-114.

Banchi A. 1904. Morfologia dele arteriaecoronariaecordis. Arch. Ital. Anat. Embriol. 3:87-164.

Bossi V. 1909. Angiologia, p.77-79. In: Bossi V., Caradonna G.B., Spampani G., Varaldi L. \& Zimmerl U. (Eds), Trattato di Anatomia Veterinaria. Vol.2. Francesco Vallardi, Milano. 
Bruni A.C. \& Zimmerl U. 1977. Anatomia degli Animali Domestici. Vol.2. Francesco Vallardi, Milano. 736p.

Dixon J.A. \& Spinale F.G. 2009. Large Animal Models of Heart Failure: a critical link in the translation of basic science to clinical practice. Circ. Heart Fail. 2(3):262-271.

Dyce K.M., Sack W.O. \& Wensing C.J.G. 1990. Tratado de Anatomia Veterinaria. Guanabara Koogan, Rio de Janeiro, p.151-152.

Ellenberger W. \& Baum H. 1977. Handbuch der vergleichenden Anatomie der Haustiere. 17. Aufl. Julius Springer, Berlin. 629p.

Garcia G.J. \& Alvarez G.R. 1961. Anatomia Comparada de los Animals Domesticos. 7aㅡ ed. Canales, Madrid, p.621-622.

Grehan J., Hilbert S. \& Ferrans V. 2000. Development and evaluation of a swine model to assess the preclinical safety of mechanical heart valves. J. Heart Valve Dis. 9(5):710-719.

Guiney E.J. 1965. The pig as an experimental animal with particular reference to cardiovascular surgery. Ir. J. Med. Sci. 40(6):273-280.

Habermehl K.H. 1959. Die Blutgefässversorgung dese Katzenherzens. Zentralbl. Veterinärmed. 6:655-680.

Hendry P.J., Ascah K.J., Rajagopalan K. \& Calvin J.E. 1994. Does septal position affect right ventricular function during left ventricular assist in an experimental porcine model? Circulation 90(5, Pt 2):353-358.

Hoffmann V. 1975. Die Blutgefässversorgung des Pferdeherzens: zugleich auch eine vergleichende Betrachtung der Topographie der herzeigenen Blutgefässe der Haussäuger (Fleischfresser, Schwein und Wiederkäuer). Anat. Anz.137:79-109.

Hughes H.C. 1986. Swine in cardiovascular research. Lab. Anim. Sci. 36(4): 348-350.

International Committee on Veterinary Gross Anatomical Nomenclatura 1994. Nomina Anatômica Veterinária. 4th ed. World Association on Veterinary Anatomists, Zürich.

Kassab G.S. \& Fung Y.C. 1994. Topology and dimensions of pig coronary capillary network. Am. J. Physiol. 267(1, Pt 2):H319-H325.

Koch T. 1965. Lehrbuch der Veterinär-Anatomie. 3. Aufl. Gustav Fischer, Jena. 78p.

Lesbre F.X. 1923. Précis d'Anatomie Comparée des Animaux Domestiques. J.B. Baillière, Paris, p.285-286.

Li X., Zhang F., Song G., Gu W. \& Chen M. 2013. Intramyocardial injection of pig pluripotent stem cells improves left ventricular function and perfusion: a study in a porcine model of acute myocardial infarction. PLoS ONE 8(6):e66688.

Maluf M.A., Verde J.L., Leal J.C., Catani R., Garcia Jr H.V., Thevenard R., Carvalho A.C., Andrade J.L., Andrade J.C.S., Braile D.M., Leao L.E.V. \& Buffolo E. 1993. Reconstituição da valvapulmonar e via de saída do ventrículodireito, com prótesebivalvular e prótese tubular valvada de troncopulmonar de porco: estudo experimental e aplicaçãoclínica. Revta Bras. Cir. Cardiovasc. 8(1):20-38.

Mannu A. 1930. Apparechiovascolare, p.69-70. In: Zimmerl U. (Ed.), Trattato di Anatomie Veterinaria. Vol.2. Francesco Vallardi, Milano.
Marques P. 1962. Alguns aspectos morfológicos comparativos do coração dos mamíferos domésticos. Tipografia Nunes, Lisboa. 320p.

Martini E. 1965. La vascolarizzazione arteriosa del cuore di alcuni mammiferi domestici. Arch. Ital. Anat. Embriol. 70(1):351-380.

Min J.Y., Sullivan M.F., Yang Y., Zhang J.P., Converso K.L., Morgan J.P. \& Xiao Y.F. 2002. Significant improvement of heart function by cotransplantation of human mesenchymal stem cells and fetal cardiomyocytes in postinfarcted pigs. Ann. Thoracic. Surg. 74(5):1568-1575.

Montané L. \& Bourdelle E. 1920. Anatomie Régionale des Animaux Domestiques. Vol.3. J.B. Baillière, Paris, p.773-774.

Rickert J. 1955. Blutgefässversorgung des Schweineherzens. Inalgural Dissertation, Anatomisches Institut der Tierärztlichen Hochschule, Hannover. 44p.

Santos L.A.S., Benicio A., Mattos Jr E., Benvenutti L.A., Cestari I.A., Stolf N.A.G. \& Moreira L.F.P. 2012. Anastomose cavo-pulmonar associada ao suportecirculatório esquerdo comparada à assistência biventricular na falência cardíaca aguda. Revta Bras. Cir. Cardiovasc. 27(4):552-561.

Satyananda V., Hara H., Ezzelarab M.B., Phelps C., Ayares D. \& Cooper D.K. 2013. New concepts of immune modulation in xenotransplantation. Transplantation. 96(11):937-945.

Schummer A., Wilkens H., Vollmerhaus B. \& Habermehl K.H. 1981. The circulatory system, the skin, and the cutaneous organs of the domestic mammals, p.52-53. In: Nickel R., Schummer A. \& Seiferle E. (Eds), The Anatomy of the Domestic Animals. Paul Parey, Berlin.

Schwarze E. \& Schröder L. 1972. Compendio de Anatomia Veterinaria. Vol.3. Acribia, Zaragoza. 25p.

Sisson S. \& Grossman J.D. 1975. El gallo, p.903-923. In: Ibid. (Eds), Anatomia de los Animales Domesticos. 4를 ed. Salvat, Barcelona.

Swindle M.M. \& Adams R.J. 1988. Experimental Surgery and Physiology: induced animal models of human disease. Williams and Wilkins, Baltimore, MD. 350p.

Swindle M.M., Makin A., Herron A.J., Clubb Jr F.J. \& Frazier K.S. 2012. Swine as models in biomedical research and toxicology testing. Vet. Pathol. 49(2):344-356.

Swindle M.M. \& Smith A.C. 1998. Comparative anatomy and physiology of the pig. Scand. J. Lab. Anim. Sci. 25(Suppl.1):1-10.

Swindle M.M. 2007. Swine in the Laboratory: surgery, anesthesia, imaging and experimental techniques, p.195-259. In: Ibid. (Ed.), Cardiothoracic and Vascular Surgery: chronic intravascular catheterization. 2nd ed. CRC Press, Boca Raton, FL.

Tumbleson M.E. \& Schook L.B. 1996. Advances in Swine in Biomedical Research. Vol.1 and 2. Plenum Press, New York. 462p.

Vidotti A.P., Agreste F.R., Bombonato P.P., Prado I.M.M. \& Monteiro R. 2008. Vascularização arterial da região do nó sinoatrial em corações suínos: origem, distribuição e quantificação. Pesq. Vet. Bras. 28:113-118.

Wolf E., Braun-Reich hart C., Streckel E. \& Renner S. 2014. Genetically engineered pig models for diabetes research. Transgenic Res. 23:27-38 